\title{
Plant Growth Promotion and Biocontrol of Pythium ultimum by Saline Tolerant Trichoderma Isolates under Salinity Stress
}

\author{
Brenda Sánchez-Montesinos ${ }^{1}$, Fernando Diánez ${ }^{1}$, Alejandro Moreno-Gavira ${ }^{1}$, \\ Francisco J. Gea ${ }^{2}$ (D) and Mila Santos ${ }^{1, *}$ \\ 1 Departamento de Agronomía, Escuela Superior de Ingeniería, Universidad de Almería, 04120 Almería, \\ Spain; brensam@hotmail.com (B.S.-M.); fdianez@ual.es (F.D.); alejanmoga@gmail.com (A.M.-G.) \\ 2 Centro de Investigación, Experimentación y Servicios del Champiñón (CIES), Quintanar del Rey, \\ 16220 Cuenca, Spain; fjgea.cies@dipucuenca.es \\ * Correspondence: msantos@ual.es; Tel.: +34-950-015511
}

Received: 15 May 2019; Accepted: 4 June 2019; Published: 10 June 2019

\begin{abstract}
This present study evaluates three isolates of Trichoderma as plant growth promoting or biological control agents: Trichoderma aggressivum f. sp. europaeum, Trichoderma saturnisporum, and the marine isolate obtained from Posidonia oceanica, Trichoderma longibrachiatum. The purpose is to contribute to an overall reduction in pesticide residues in the fruit and the environment and to a decrease in chemical fertilizers, the excess of which aggravates one of the most serious abiotic stresses, salinity. The tolerance of the different isolates to increasing concentrations of sodium chloride was evaluated in vitro, as well as their antagonistic capacity against Pythium ultimum. The plant growth promoting capacity and effects of Trichoderma strains on the severity of P. ultimum on melon seedlings under saline conditions were also analysed. The results reveal that the three isolates of Trichoderma, regardless of their origin, alleviate the stress produced by salinity, resulting in larger plants with an air-dry weight percentage above $80 \%$ in saline stress conditions for T. longibrachiatum, or an increase in root-dry weight close to $50 \%$ when T. aggressivum f. sp. europaeum was applied. Likewise, the three isolates showed antagonistic activity against $P$. ultimum, reducing the incidence of the disease, with the highest response found for T. longibrachiatum. Biological control of P. ultimum by T. aggressivum $\mathrm{f}$. sp. europaeum and T. saturnisporum is reported for the first time, reducing disease severity by $62.96 \%$ and $51.85 \%$, respectively. This is the first description of T. aggressivum f. sp. europaeum as a biological control agent and growth promoter. The application of these isolates can be of enormous benefit to horticultural crops, in both seedbeds and greenhouses.
\end{abstract}

Keywords: Pythium ultimum; salt tolerance; Trichoderma; biological control; stress abiotic and biotic

\section{Introduction}

The growing concern of consumers for food safety and for the social and environmental sustainability of cultivation systems has a particular impact on the fruit and vegetable production sectors. These sectors are facing increasingly stringent restrictions that large distribution chains establish in their purchasing specifications regarding the presence of active ingredients in multi-waste pesticide analyses. These are much more restrictive than those established by community legislation itself, both in terms of the amount (less than the maximum residue limit, MRL) and in terms of the number of active substances detected that they permit [1]. This circumstance forces us to look for new tools for crop protection that are not based on chemical control. Currently, in important areas of intensive vegetable production such as Almería (Spain), there has been a notable advance in the biological control of pests, but not in that of diseases, the latter still being quite dependent on the use 
of agrochemicals. The use of microorganisms as biological control agents (BCAs) of diseases is one of the keys to production with less phytosanitary residues and greater food safety. In addition, many of the BCAs marketed act as promoters of plant growth. This circumstance permits action on another of the important problems of intensive production systems, environmental pollution due to the excessive use of fertilizers. The search for new tools to reduce the use of pesticides and chemical fertilizers is a goal that must be achieved in the medium term.

The productivity of agricultural lands in arid and semi-arid environments is affected by the accumulation of salts and the loss of soil organic matter [2]. The salinity of the soil, as well as the use of water with a high salt content for irrigation, leads to a reduction in plant growth and crop yields $[3,4]$. Likewise, the presence of salts affects the assimilation of nutrients by plants and the microbial activity of the soil. In addition, it increases the severity of the effects of phytopathogens and influences biological control agents and the interaction among them. There are numerous references to the buffering role of microorganisms in the plant rhizosphere [4-6]. Generally, this effect is due to molecular, biochemical and physiological changes in the plant elicited by microorganisms [7]. Paecilomyces formosus mitigates the negative impact of salt stress on cucumber plants by producing gibberellins and indoleacetic acid [8]. Likewise, the association with endophytic fungi such as Penicillium sp. and Phoma glomerata alters jasmonic acid levels, increases salicylic acid values and reduces abscisic acid synthesis, reducing the detrimental effects of salinity [9]. Coinoculation of Aspergillus niger and Trichoderma harzianum alleviates the deleterious effects of salt stress on wheat seedlings through the solubilisation of $P$ and joint production of indoleacetic acid [10]. Yasmeen and Siddiqui [11] detected that the presence of Trichoderma in a saline environment increased the activity of antioxidant enzymes. Studies carried out with T. harzianum confirmed its high soil colonisation and yield in the production of tomatoes grown under plastic with high-salinity irrigation [12]. Nevertheless, there are microorganisms that are not adapted to conditions of high salinity. Such is the case for some isolates of Trichoderma, whose biofungicide and plant promoter role may be compromised by their low osmotolerance $[13,14]$. For this reason, numerous studies have been carried out in the search for halotolerant biological control agents. Gal-Hemed et al. [15] isolated T. atroviride and T. asperelloides from the Mediterranean sponge Psammocinia sp. capable of reducing Rhizoctonia solani damping-off disease in beans and also inducing defence responses in cucumber seedlings against Pseudomonas syringae pv. lachrymans. Likewise, Trichoderma isolates of marine sediments, invertebrates and algae have been obtained [16,17]. On the other hand, breeding of Trichoderma has been conducted, with the same objective of increasing the benefits of biological control, as well as resisting adverse conditions [13].

Therefore, the goals of the present study were: (a) to evaluate the tolerance of different concentrations of $\mathrm{NaCl}$ on three isolates of Trichoderma obtained from suppressive soils, mushroom culture substrates, and Posidonia oceanica; (b) to evaluate the in vitro antagonistic capacity of these isolates against Pythium ultimum; (c) to study the capacity to promote the growth of melon seedlings of Trichoderma strains under increasing salinity concentrations; and finally, (d) to evaluate the biological control of the disease caused by P. ultimum in melon seedlings, exerted by Trichoderma strains under various levels of salt stress.

\section{Materials and Methods}

\subsection{Fungal Isolates}

The isolates selected in this study have been obtained from different environments. Trichoderma saturnisporum-(TS), obtained from suppressive soils, was selected for its known antagonistic activity and plant growth promotion in pepper and melon [18,19]. Trichoderma aggressivum f. sp. europaeum Tae52481 (TA) was isolated from samples of substrate used for Agaricus bisporus cultivation from mushroom farms located in Castilla-La Mancha (Spain). Trichoderma longibrachiatum (TL) was isolated from the roots of the endemic seagrass, Posidonia oceanica, sampled from the 
Mediterranean Sea in Almeria, Spain, following the procedure of Vohník et al. [20]. Both were isolated by serial dilution technique on potato dextrose agar (PDA) medium and incubated at $25^{\circ} \mathrm{C}$ for $5-7$ days.

Colony morphology of the pure cultured isolates TL and TA on potato dextrose agar (PDA, Difco) and conidiophore morphology examined by light microscopy and cryo-fracturing electron scanning microscopy (cryo-sem) [18] were consistent with the genus Trichoderma (Figure 1). Molecular identification of the selected fungi was conducted following the procedure described by Diánez et al. [18]. The sequence was analysed using a BLAST search in the GenBank database of the National Centre for Biotechnology Information (NCBI, http://blast.ncbi.nlm.nih.gov/Blast.cgi) and aligned to the nearest neighbours. The sequences have not been deposited in the GenBank database as they are subject to patent.

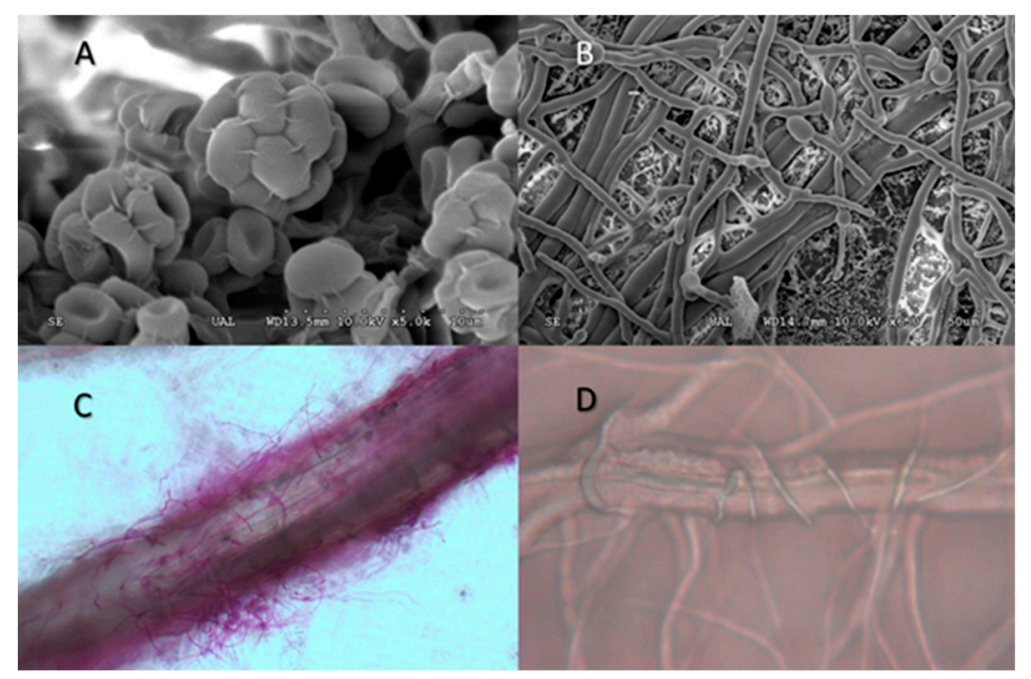

Figure 1. Trichoderma isolates examined by electron and light microscopy. (A) Conidiophores with conidia of Trichoderma longibrachiatum; (B) Hyphae of Trichoderma saturnisporum; (C) Trichoderma aggressivum colonisation on melon root. (D) T. aggressivum mycelia around mycelium of Pythium ultimum.

Melon seedlings showing lesions caused by Pythium ultimum were selected to obtain the inoculum, which was used as the test pathogen in antagonistic in vitro and in vivo assays.

Each isolate was grown on PDA for 5 or 15 days at $25-27 \pm 2{ }^{\circ} \mathrm{C}$ under dark conditions. Spore suspensions of Trichoderma isolates were prepared by flooding plates of 15-day-old cultures with sterile distilled water, scraping with a sterile glass rod and filtering, and adjusted to a concentration of $1 \cdot 10^{8}$ spores/mL with a Neubauer haemocytometer.

\subsection{Growth Conditions of the Fungal Strains in PDA with Differing Concentrations of $\mathrm{NaCl}$}

Trichoderma and phytopathogen strains were cultured at $25^{\circ} \mathrm{C}$ for 7 days in PDA. Mycelium discs ( $5 \mathrm{~mm}$ diameter) were obtained from the edges of the PDA plates and inoculated into new PDA, amended with various concentrations of $\mathrm{NaCl}\left(0,1,2,5,10,15\right.$ or $\left.20 \mathrm{~g} \cdot \mathrm{L}^{-1}\right)$. The plates were incubated for 7 days at 25 and $35^{\circ} \mathrm{C}$. The colony diameters were recorded every day during culturing. The experiment was completely randomised with five replicates. Salt tolerance capacity of Trichoderma isolates was measured as the percentage reduction in linear growth calculated by $(C-N) \cdot 100 / C$, where $\mathrm{N}$ is the maximum radius of the isolates grown on $\mathrm{NaCl}$-supplemented medium and $\mathrm{C}$ is the radius of the isolates grown on $\mathrm{NaCl}$-free medium.

\subsection{Dual Culture Antagonism Assays}

Trichoderma isolates were screened for their antagonism against Pythium ultimum by the confrontation assay of Santos and Diánez [21]. Petri dishes $(9 \mathrm{~cm}$ diameter) containing $15 \mathrm{~mL}$ of PDA were prepared, amended with different concentrations of $\mathrm{NaCl}\left(0,1,2,5,10,15\right.$, or $\left.20 \mathrm{~g} \cdot \mathrm{L}^{-1}\right)$. 
Petri dishes were sealed with parafilm and incubated in the dark at $25^{\circ} \mathrm{C}$ for $4-7$ days, until the growth in the control plates reached the edge of the plates. The plates were then assessed by measuring the distances between pathogen and fungal cultures. Results were transformed into percentages of mycelium growth inhibition. These tests were carried out in quintuplicate.

\subsection{Evaluation of Growth Promotion Effects of Trichoderma Isolates on Melon Seedlings under Salinity Stress}

To determine the promoter effect of the different isolates of Trichoderma, melon seeds of the variety Piñonet (Piel de sapo) were disinfected with $2 \%$ hypochlorite for $3 \mathrm{~min}$ and washed abundantly with tap water to eliminate residues. Subsequently, the seeds were pregerminated in darkness in a humid room at $25^{\circ} \mathrm{C}$ and transplanted to $300 \mathrm{~mL}$ pots into a commercial peat mix, with one seed per pot. Simultaneously to sowing, $5 \mathrm{~mL}$ of water (T0) or $5 \mathrm{~mL}$ spore suspension of each isolate of Trichoderma (TS, TA, or TL) was placed in each pot at $50 \times 10^{6}$ propagules/plant. The experiment was performed under greenhouse conditions. Each treatment consisted of 25 repetitions. Plants were fertilized daily with a commercial complex nutrient fertilizer. When the first true leaf had fully expanded, four different levels of $\mathrm{NaCl}$ concentrations, $0,0.5,1,1.5$ or $2 \mathrm{~g} \cdot \mathrm{L}^{-1}$, were given by manually drenching the media with approximately $50 \mathrm{~mL}$ of the solutions, once per day for 30 days, and with $100 \mathrm{~mL}$ per day for the following days, as the plants grew. The electrical conductivity (EC) of the solutions was recorded to be $2.1,3.87,5.30,6.6$ and $7.16 \mathrm{dS} \cdot \mathrm{m}^{-1}$. After 45 days of culture, 10 plants per treatment and control were analysed. Dry and fresh weight of the aerial part and roots were determined.

\subsection{Effects of Trichoderma Strains on the Severity of Pythium Ultimum in Melon Seedlings under Saline Conditions}

To obtain zoospores of Pythium ultimum, the procedure described by Marin et al. was followed [22]. The concentration of the zoospore suspension was adjusted to approx. $10^{3}$ zoospores $\cdot \mathrm{mL}^{-1}$, using a haemocytometer. The inoculum was used immediately, and $5 \mathrm{~mL}$ of the suspension was applied uniformly over the surface of the peat in each pot using a sterile micropipette. The pathogenicity test of P. ultimum on melon seedlings was carried out under greenhouse conditions, in the same manner as described above. The application of P. ultimum was performed after complete expansion of the second true leaf. The application of the different salt concentrations was carried out in the same manner as for the growth promotion test described above. Symptom severity was rated periodically, and a final disease severity index was estimated according to the following scale [23]: 0-healthy plant; 1 -symptoms beginning; 2 -moderate symptoms; 3 - severely affected plant; and 4-dead plant. The experiments were conducted using completely randomised block designs.

\subsection{Statistical Analysis}

All data presented are the mean of five replicates of in vitro tests and ten replicates of pot experiments. Data were analysed using analysis of variance, conducted using the Statgraphics Centurion ver. XVI software. Results are expressed as mean value \pm standard error of the mean. $p$-values less than 0.05 were considered to be significant.

\section{Results}

\subsection{Effects of Salinity and Temperature on Colony Growth of Trichoderma Isolates}

In Figure 2, the results obtained from mycelial growth of TS, TA, and TL are shown at different salt concentrations and temperatures $\left(25\right.$ and $\left.35^{\circ} \mathrm{C}\right)$. As expected, there was no inhibition of TL mycelial growth at the different salt concentrations tested, nor were there differences in growth at 25 and $35^{\circ} \mathrm{C}$. However, for both TS and TA, the presence of salt in the medium conditioned growth. This resulted in a drastic reduction of mycelial growth, from 66.9 (TS) and 76.75\% (TA) from 2 and $10 \mathrm{~g} \cdot \mathrm{L}^{-1}$, respectively. The temperature of $35^{\circ} \mathrm{C}$ completely inhibited the mycelial growth of TA. No reduction in growth of P. ultimum was observed at $25^{\circ} \mathrm{C}$ as salt concentration increased, except at $20 \mathrm{~g} \cdot \mathrm{L}^{-1}$. No growth at $35^{\circ} \mathrm{C}$ (Figure 2) was observed. 


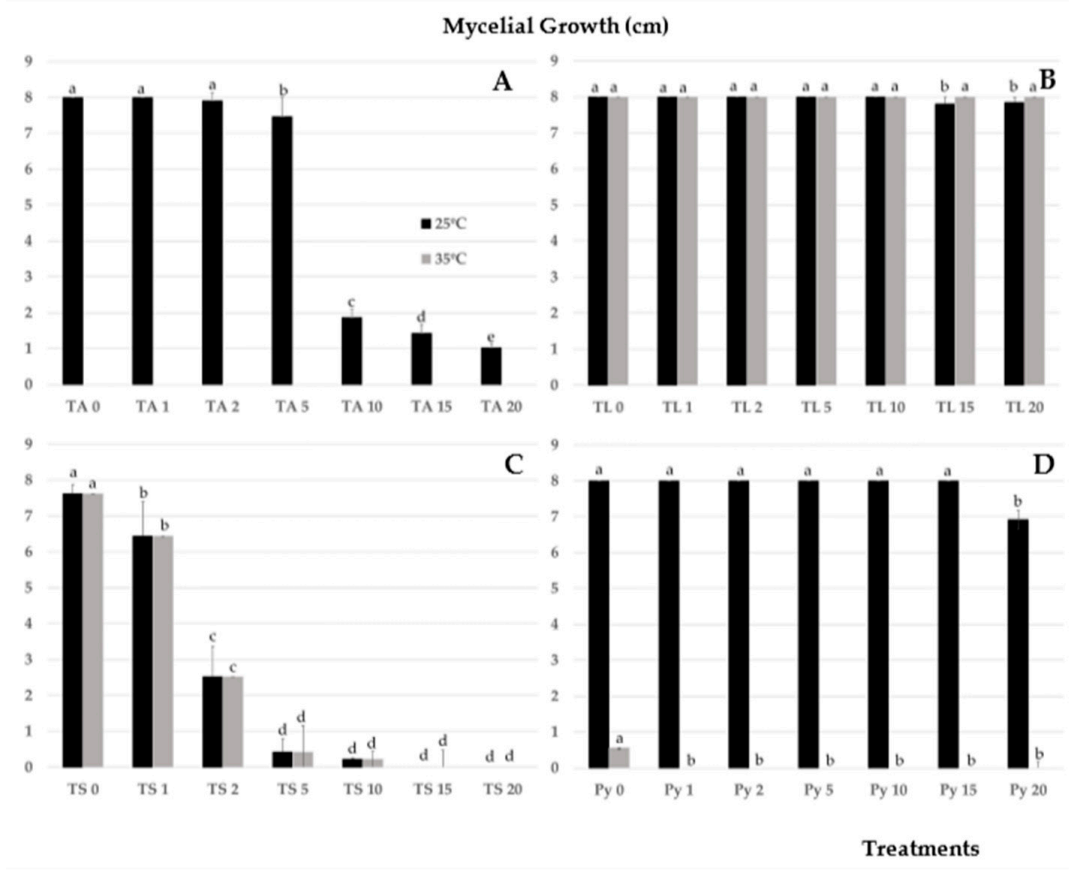

Figure 2. Mycelial growth (cm) of Trichoderma isolates as affected by different concentrations of $\mathrm{NaCl}\left(0-20 \mathrm{~g} \cdot \mathrm{L}^{-1}\right)$ and temperatures $\left(25 / 35{ }^{\circ} \mathrm{C}\right)$. (A) Trichoderma aggressivum f. sp. europaeum. (B) T. longibrachiatum. (C) T. saturnisporum. (D) Pythium ultimum. Mean standard deviation is expressed in error bar $(n=5)$. For each isolate, columns marked with different letters indicate a significant difference at $p<0.05$.

\subsection{Effects of Trichoderma Isolates on the Radial Growth of P. ultimum}

In Figure 3, the results obtained from the microbial antagonism for P. ultimum are observed. The highest percentages of inhibition of mycelial growth corresponded to the confrontations with TL, which were not affected under conditions of increasing salinity. The decrease in growth of TA and TS antagonist isolates had an impact on the microbial antagonism detected as the concentration of medium salt increased. Despite this, microbial antagonism values were high, considering the characteristic mycelial growth rate of this pathogen at any salt concentration.

\begin{tabular}{|c|c|c|c|c|c|c|c|}
\hline & $\mathrm{NaCl}(0-20 \mathrm{~g}$. & & & & & & \\
\hline Dual Culture & 0 & 1 & 2 & 5 & 10 & 15 & 20 \\
\hline TS-Py & & & & - & - & - & - \\
\hline \multirow[t]{2}{*}{ TL-Py } & & & & & & & \\
\hline & $59.50 \pm 11.65^{c}$ & $66.00 \pm 9.81^{b, c}$ & $72.50 \pm 3.42^{2 \mathrm{bb}}$ & $60.75 \pm 9.95^{\circ}$ & $79.75 \pm 1.63^{2}$ & $68.40 \pm 2.84^{b, c}$ & $71.15 \pm 4.39 \mathrm{ab}$ \\
\hline \multirow[t]{2}{*}{ TA-Py } & & & & & - & - & - \\
\hline & $53.50 \pm 4.48^{\mathrm{a}}$ & $51.25 \pm 6.84^{a}$ & $55.00 \pm 13.32^{\mathrm{a}}$ & $37.00 \pm 3.26^{6}$ & & & \\
\hline
\end{tabular}

Figure 3. Antagonistic potential of Trichoderma isolates against P. ultimun (Py) in dual culture at different salinity levels on potato dextrose agar (PDA) medium. \% mycelial inhibition was calculated as 
PIRG $=(R 1-R 2) \div R 1 \times 100$, where: PIRG: percentage inhibition of radial mycelia growth of the pathogen, R1: radial growth of pathogen in control plates, R2: radial growth of pathogen in dual culture plates. $\mathrm{a}, \mathrm{b}$ and $\mathrm{c}$ Means with the same letter are not significantly different (LSD) according to ANOVA test $(p<0.05)$.

\subsection{Promoter Effects of Trichoderma Isolates on Melon Seedlings and Salinity Treatments}

The effect of Trichoderma isolate application by irrigation on morphological parameters is shown in Table 1. The application of TS, TL and TA resulted in increases of both the aerial and radical part of the plant. These increases were statistically significant in some cases. Such promotion of plant growth also occurs under conditions of saline stress.

Table 1. Morphological parameters of melon plants treated with different doses of $\mathrm{NaCl}$ and Trichoderma isolates.

\begin{tabular}{ccccc}
\hline $\begin{array}{c}\text { Treatments } \\
\left.\text { Isolate/NaCl (g. } \mathbf{L}^{-1}\right)\end{array}$ & $\begin{array}{c}\text { Aereal Fresh } \\
\text { Weight (g) }\end{array}$ & $\begin{array}{c}\text { Root Fresh } \\
\text { Weight (g) }\end{array}$ & $\begin{array}{c}\text { Aereal Dry } \\
\text { Weight (g) }\end{array}$ & $\begin{array}{c}\text { Root Dry } \\
\text { Weight (g) }\end{array}$ \\
\hline T0-0 & $6.74 \pm 1.93^{\mathrm{c}}$ & $1.61 \pm 0.70^{\mathrm{b}, \mathrm{c}}$ & $0.48 \pm 0.15^{\mathrm{b}}$ & $0.09 \pm 0.06^{\mathrm{b}}$ \\
TS-0 & $7.92 \pm 1.79^{\mathrm{a}}$ & $2.31 \pm 0.50^{\mathrm{a}}$ & $0.78 \pm 0.16^{\mathrm{a}}$ & $0.13 \pm 0.02^{\mathrm{a}}$ \\
TA-0 & $7.01 \pm 0.98^{\mathrm{b}, \mathrm{c}}$ & $1.59 \pm 0.85^{\mathrm{b}, \mathrm{c}}$ & $0.71 \pm 0.12^{\mathrm{a}}$ & $0.12^{\mathrm{a}} \pm 0.03^{\mathrm{a}}$ \\
TL-0 & $7.27 \pm 1.71^{\mathrm{b}}$ & $1.74 \pm 0.49^{\mathrm{b}}$ & $0.76 \pm 0.07^{\mathrm{a}}$ & $0.10 \pm 0.04^{\mathrm{a}, \mathrm{b}}$ \\
\hline T0-0.5 & $6.94 \pm 1.80^{\mathrm{b}}$ & $1.42 \pm 0.42^{\mathrm{b}}$ & $0.37 \pm 0.09^{\mathrm{c}}$ & $0.07 \pm 0.03^{\mathrm{b}}$ \\
TS-0.5 & $7.19 \pm 1.77^{\mathrm{a}, \mathrm{b}}$ & $1.68 \pm 0.54^{\mathrm{a}}$ & $0.55 \pm 0.11^{\mathrm{b}}$ & $0.08 \pm 0.02^{\mathrm{a}, \mathrm{b}}$ \\
TA-0.5 & $7.49 \pm 1.34^{\mathrm{a}}$ & $1.70 \pm 0.61^{\mathrm{a}}$ & $0.66 \pm 0.16^{\mathrm{a}, \mathrm{b}}$ & $0.09 \pm 0.02^{\mathrm{a}}$ \\
TL-0.5 & $7.05 \pm 1.22^{\mathrm{b}}$ & $1.39 \pm 0.48^{\mathrm{a}, \mathrm{b}}$ & $0.69 \pm 0.23^{\mathrm{a}}$ & $0.08 \pm 0.03^{\mathrm{a}, \mathrm{b}}$ \\
\hline T0-1 & $5.32 \pm 1.45^{\mathrm{b}}$ & $0.93 \pm 0.55^{\mathrm{b}}$ & $0.39 \pm 0.18^{\mathrm{b}}$ & $0.07 \pm 0.03^{\mathrm{a}, \mathrm{b}}$ \\
TS-1 & $6.01 \pm 1.30^{\mathrm{a}}$ & $1.02 \pm 0.35^{\mathrm{b}}$ & $0.49 \pm 0.11^{\mathrm{a}, \mathrm{b}}$ & $0.06 \pm 0.02^{\mathrm{c}}$ \\
TA-1 & $5.90 \pm 1.05^{\mathrm{a}, \mathrm{b}}$ & $1.46 \pm 0.42^{\mathrm{a}}$ & $0.76 \pm 0.12^{\mathrm{a}}$ & $0.10 \pm 0.01^{\mathrm{a}}$ \\
TL-1 & $6.30 \pm 2.43^{\mathrm{a}}$ & $1.35 \pm 0.46^{\mathrm{a}}$ & $0.77 \pm 0.16^{\mathrm{a}}$ & $0.07 \pm 0.03^{\mathrm{a}, \mathrm{b}}$ \\
\hline T0-1.5 & $5.26 \pm 1.40^{\mathrm{c}}$ & $0.67 \pm 0.35^{\mathrm{c}}$ & $0.39 \pm 0.09^{\mathrm{c}}$ & $0.07 \pm 0.04^{\mathrm{a}, \mathrm{b}}$ \\
TS-1.5 & $5.57 \pm 1.03^{\mathrm{b}}$ & $1.02 \pm 0.24^{\mathrm{b}}$ & $0.50 \pm 0.15^{\mathrm{b}}$ & $0.05 \pm 0.02^{\mathrm{b}}$ \\
TA-1.5 & $7.43 \pm 1.79^{\mathrm{a}}$ & $1.27 \pm 0.25^{\mathrm{a}}$ & $0.63 \pm 0.18^{\mathrm{a}}$ & $0.09 \pm 0.02^{\mathrm{a}}$ \\
TL-1.5 & $5.07 \pm 0.87^{\mathrm{c}}$ & $1.04 \pm 0.23^{\mathrm{b}}$ & $0.50 \pm 0.11^{\mathrm{b}}$ & $0.08 \pm 0.02^{\mathrm{a}}$ \\
\hline T0-2 & $5.22 \pm 1.12^{\mathrm{c}}$ & $0.55 \pm 0.28^{\mathrm{b}}$ & $0.44 \pm 0.14^{\mathrm{b}}$ & $0.07 \pm 0.03^{\mathrm{a}}$ \\
TS-2 & $5.82 \pm 0.83^{\mathrm{b}}$ & $0.72 \pm 0.28^{\mathrm{a}}$ & $0.51 \pm 0.13^{\mathrm{a}}$ & $0.05 \pm 0.02^{\mathrm{b}}$ \\
TA-2 & $6.35 \pm 1.00^{\mathrm{a}}$ & $1.08 \pm 0.21^{\mathrm{a}}$ & $0.58 \pm 0.08^{\mathrm{a}}$ & $0.07 \pm 0.03^{\mathrm{a}}$ \\
TL-2 & $5.42 \pm 1.18^{\mathrm{b}, \mathrm{c}}$ & $0.82 \pm 0.33^{\mathrm{a}}$ & $0.49 \pm 0.12^{\mathrm{a}, \mathrm{b}}$ & $0.07 \pm 0.03^{\mathrm{a}}$ \\
\hline
\end{tabular}

a, b, c Values of a column followed by the same letters have no significant difference at $5 \%$ (LSD test).

The highest values were detected for TS at $0 \mathrm{~g} \cdot \mathrm{L}^{-1}$, where there was an increase in the fresh and dry weight of the aerial and radical parts of $17.5,62.11,44.02$ and $46.51 \%$, respectively. For the different salinity concentrations tested, plant growth promotion was also observed in the dry weight of the aerial part, which decreased as the salt content in the water increased (from $50.13 \%$ at $0.5 \mathrm{~g} \cdot \mathrm{L}^{-1}$ to $17.16 \%$ at $\left.2 \mathrm{~g} \cdot \mathrm{L}^{-1}\right)$. However, there was a very marked decrease in the root, going from a $5.4 \%$ increase in the root at $0.5 \mathrm{~g} \cdot \mathrm{L}^{-1}$ to a $20 \%$ decrease at $2 \mathrm{~g} \cdot \mathrm{L}^{-1}$, relative to that of the control.

The application of TL also promoted melon seedlings growth, increasing the dry weight of the aerial part by $58.17,87.94,94.92,27.10$ and $12.12 \%$ in $\mathrm{NaCl}$ concentrations of $0-2 \mathrm{~g} \cdot \mathrm{L}^{-1}$, respectively. Likewise, an increase in the dry weight of the root was also observed for all the treatments tested, reaching a maximum of $22 \%$ for a concentration at $1.5 \mathrm{~g} \cdot \mathrm{L}^{-1}$.

In the case of the application of TA, there was an increase in both the aerial part and the very important radical part, relative to that of the control, in all the treatments tested. Thus, increases of 48 , $80.54,93.90,61.89$, and $32.72 \%$ were obtained for the dry weight of the aerial part, and increases of 
$41.80,16.21,56.92,32.35$, and $0 \%$, for the dry weight of the root, for $\mathrm{NaCl}$ concentrations between 0 and $2 \mathrm{~g} \cdot \mathrm{L}^{-1}$, respectively.

\subsection{Effects of Trichoderma Strains on the Severity of Pythium ultimum in Melon Seedlings under Saline Conditions}

The application of sodium chloride in irrigation water has not led to a significant increase $(p=0.4699)$ in the symptoms caused by P. ultimum in melon seedlings relative to that of the control $\left(0 \mathrm{~g} \cdot \mathrm{L}^{-1}\right)$. As determined in greenhouse experiments, three strains (TA, TS and TL) significantly reduced the disease index of P. ultimum root rot in melon seedlings, compared to that achieved by the control $\mathrm{T} 0$, for the different $\mathrm{NaCl}$ concentrations tested (Figure 4).

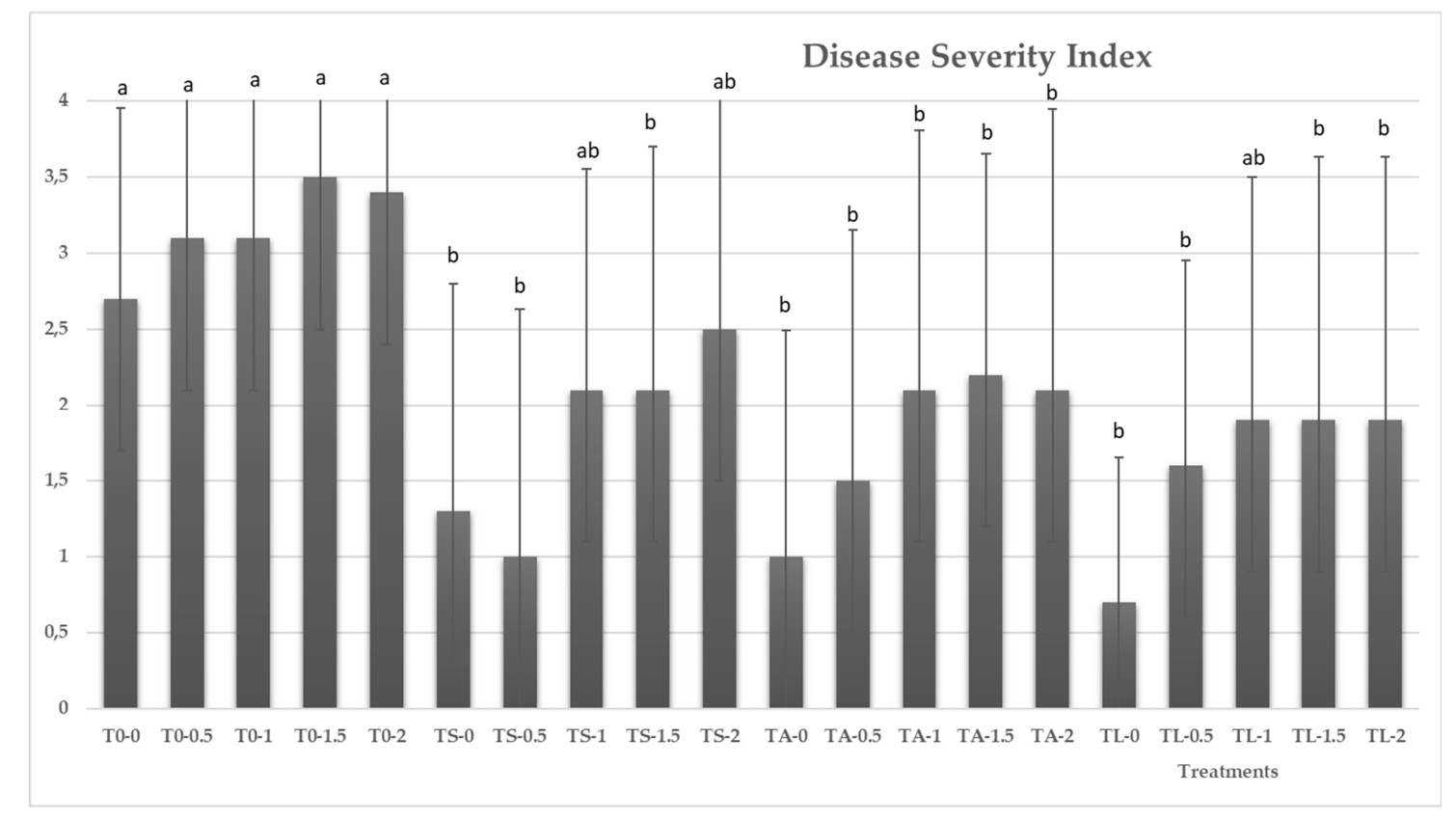

Figure 4. Disease incidence of P. ultimum in melon plants was rated 30 days after inoculation based on a $0-4$ scale: where $0=$ no visible disease symptoms and $4=$ plant dead. Mean standard deviation is expressed in error bar $(n=10)$. ${ }^{\mathrm{a}, \mathrm{b}, \mathrm{c}}$ Means with the same letter are not significantly different (LSD) according to ANOVA test $(p<0.05)$.

Thus, at $0 \mathrm{~g} \cdot \mathrm{L}^{-1}$, the severity of the disease was reduced by $74 \%$ by the marine isolate $\mathrm{TL}$, followed by TS and TA, with readings of $51.85 \%$ and $62.96 \%$, respectively, relative to that of the control $(p=0.0086)$. There were no significant differences in the ability to control the onset of symptoms in the three isolates of Trichoderma tested. In general, as salt content in irrigation water increased, there were no significant differences in the control of disease caused by P. ultimum for the three isolates of Trichoderma assayed, significantly reducing the symptoms with respect to the control (T0). TL performed greater control of the development of the disease, reaching a reduction of $44.11 \%$ for $2 \mathrm{~g} \cdot \mathrm{L}^{-1}$ of $\mathrm{NaCl}$.

\section{Discussion}

The capacity of using fungal isolates for biological control of diseases or promotion of the growth of plants under cultivation conditions may be conditioned by management, soil conditions or fertigation, temperature, salinity and the presence of heavy metals or pesticides, amongst many other factors. The saline conditions, caused in many cases by excessive chemical fertilisation in intensive horticulture, may call into question the effectiveness of these BCAs. In this study, we have analysed the capacity of isolates of Trichoderma obtained from different environments to promote the development of melon seedlings and to control root rot caused by P. ultimum under saline stress conditions. Isolates from 
mushroom culture substrates and rhizomes of Posidonia oceanica were identified as T. aggressivum f. sp. europaeum and T. longibrachiatum, respectively.

With the exception of TL, the mycelial growth of TA and TS has been influenced by salinity and temperature. The relationship between temperature and the development of Trichoderma depends in many cases on the species and the origin of the isolation. Thus, TA showed considerable differences in growth, depending on temperature $\left(25\right.$ and $\left.35^{\circ} \mathrm{C}\right)$. Similar results were obtained by Sobieralski et al. [24], whose isolates of T. aggressivum f. europaeum exhibited very poor growth at a temperature of $35^{\circ} \mathrm{C}$. Both TS and TA drastically reduced mycelial growth in a saline medium. Given the origin of TA, it is logical to presume it has a low tolerance to the presence of salt in the medium. However, this is not so for TS, since it was isolated from sand in the seabed of the coast of Cadiz (Spain), which showed suppressiveness against Fusarium oxysporum f. sp. dianthi [25]. At $30 \mathrm{~g} \cdot \mathrm{L}^{-1}$, its growth and sporulation was optimal after its isolation (Diánez F., personal communication), although this growth capacity was reduced after its growth in vitro. De la Cruz et al. [26] consider that there is no significant correlation between marine habitat and salt tolerance of fungal isolates, so it is unclear why marine fungi have different degrees of tolerance to salt, or why they lose that tolerance.

We have shown that TA, TS, and TL can inhibit the development of P. ultimum in vitro and are effective in reducing disease severity in melon seedlings, even under saline stress conditions. Given the growth capacity of P. ultimum at concentrations of $20 \mathrm{~g} \cdot \mathrm{L}^{-1}$, it is necessary to apply saline stress tolerant microorganisms that do not lose their antagonistic capabilities against phytopathogens. Migheli et al. [27] showed the capacity of T. longibrachiatum CECT2606 to reduce the incidence of damping-off in cucumber, and the role of cellulases in the control of this disease. Recently, Yuan et al. [28] showed the capacity of $T$. longibrachiatum $\mathrm{H} 9$ as a growth promoter of cucumber plants and as BCA, reducing the disease index of gray mold caused by Botrytis cinerea by induced resistance. TL has been termed probiotic thanks to the multiple benefits to the associated host tomato plants and in disease control [29]. Plant probiotic microorganisms (PPM), also known as bioprotectants, biocontrollers, biofertilizers or biostimulants, are beneficial microorganisms that provide an alternative to the use of pesticides and fertilizers, by reducing environmental and public health problems [30].

Trichoderma saturnisporum has been described as a biostimulant in pepper, melon and Arabidopsis thaliana $[18,19,31]$ plants, as well as BCA against Phytophthora parasitica, P. capsici [18] and Fusarium oxysporum [31]. New marine TS isolates from Dictyonella incisa sponge have recently been described, characterising new secondary metabolites of this species involved in disease control [32].

For the first time, this paper describes the promotion of plant growth and the control of P. ultimum by means of Trichoderma aggressivum f. sp. europaeum. In Europe, this fungus produces very serious decreases in mushroom yield [33,34]. There are no references to this fungus as a phytopathogenic agent. Its high mycelial growth and sporulation, as well as its high power as a pathogen, make TA a promising BCA.

There are numerous references based on the important role played by different species of Trichoderma in both plant promotion and biological disease control. The characterisation of the mechanisms involved is well studied and in continuous development [35-37]. However, in intensive horticulture under plastic, the benefits of the application of biostimulants or biofungicides based on Trichoderma or other microorganisms are in question, due to the perception that farmers have of the low efficacy of these products as disease controllers when compared with the rapid response presented by a chemical fertilizers or fungicide. The current changes in legislation regarding the reduction of active ingredients [38] and the commercialisation of biostimulants and biopesticides, together with the need to increase the sustainability of agriculture in terms of public health and the environment, require the use of PPM as a key element in intensive horticulture.

\section{Conclusions}

The three isolates of Trichoderma studied have shown different degrees of tolerance to the presence of $\mathrm{NaCl}$, demonstrating antagonism in vitro against P. ultimum. The marine isolate T. longibrachiatum 
did not lose antagonist activity at high salt concentrations $\left(20 \mathrm{~g} \cdot \mathrm{L}^{-1}\right)$. The present results clearly demonstrate that Trichoderma aggressivum f. sp. europaeum, T. saturnisporum and T. longibrachiatum were effective promoters of plant growth and reduced the rate of radicular putrification caused by P. ultimum in melon seedlings under saline stress conditions. This paper is the first description of Trichoderma aggressivum f. sp. europaeum as a plant promoter and BCA.

\section{Patents}

The isolated Trichoderma aggressivum $\mathrm{f}$. sp. europaeum has been deposited in the CECT and is undergoing patentability studies, with nEPMO reference number P201731151.

Author Contributions: F.D. and M.S. conceived and designed the experiments; B.S.-M. and A.M.-G. performed the experiments; B.S.-M., F.J.G. and M.S. analyzed the data; M.S. wrote the paper.

Funding: This research received no external funding.

Acknowledgments: The present work benefited from the input of the project RTC-2017-6486-2 was supported by the Spanish Ministry of Science, Innovation and Universities.

Conflicts of Interest: The authors declare that there is no conflict of interests regarding the publication of this manuscript.

\section{References}

1. Riesgos Asociados a la Presencia Simultánea de Plaguicidas en Alimentos: La Importancia de Los Análisis Multi-Residuo. Available online: https://www.ainia.es/tecnoalimentalia/tecnologia/riesgos-asociados-a-lapresencia-simultanea-de-plaguicidas-en-alimentos/ (accessed on 12 May 2019).

2. Munns, R. Genes and salt tolerance: Bringing them together. New Phytol. 2005, 167, 645-663. [CrossRef] [PubMed]

3. Paul, D. Osmotic stress adaptations in rhizobacteria. J. Basic Microbiol. 2012, 53, 101-110. [CrossRef] [PubMed]

4. Qin, Y.; Druzhinina, I.S.; Pan, X.; Yuan, Z. Microbially Mediated Plant Salt Tolerance and Microbiome-based Solutions for Saline Agriculture. Biotechnol. Adv. 2016, 34, 1245-1259. [CrossRef] [PubMed]

5. Shrivastava, P.; Kumar, R. Soil salinity: A serious environmental issue and plant growth promoting bacteria as one of the tools for its alleviation. Saudi J. Biol. Sci. 2015, 22, 123-131. [CrossRef] [PubMed]

6. Zhang, F.; Wanga, Y.; Liu, C.; Chen, F.; Ge, H.; Tian, F.; Yanga, T.; Ma, K.; Zhang, Y. Trichoderma harzianum mitigates salt stress in cucumber via multiple responses. Ecotoxicol. Environ. Saf. 2019, 170, 436-445. [CrossRef] [PubMed]

7. Kaushal, M.; Wani, S.P. Rhizobacterial-plant interactions: Strategies ensuring plant growth promotion under drought and salinity stress. Agric. Ecosyst. Environ. 2016, 231, 68-78. [CrossRef]

8. Khan, A.L.; Hamayun, M.; Kang, S.M.; Kim, Y.H.; Jung, H.Y.; Lee, J.H.; Lee, I.J. Endophytic fungal association via gibberellins and indole acetic acid can improve plant growth under abiotic stress: An example of Paecilomyces formosus LHL10. BMC Microbiol. 2012, 12, 3. [CrossRef]

9. Waqas, M.; Khan, A.L.; Kamran, M.; Hamayun, M.; Kang, S.M.; Kim, Y.H.; Lee, I.J. Endophytic fungi produce gibberellins and indoleacetic acid and promotes host-plant growth during stress. Molecules 2012, 17, 10754-10773. [CrossRef]

10. Gaind, S. Phosphate dissolving fungi: Mechanism and application in alleviation of salt stress in wheat. Microbiol. Res. 2016, 193, 94-102. [CrossRef]

11. Yasmeen, R.; Siddiqui, Z.S. Ameliorative effects of Trichoderma harzianum on monocot crops under hydroponic saline environment. Acta Physiol. Plant. 2018, 40, 4. [CrossRef]

12. Daliakopoulos, I.N.; Apostolakis, A.; Wagner, K.; Deligianni, A.; Koutskoudis, D.; Stamatakis, A.; Tsanis, I.K. Effectiveness of Trichoderma harzianum in soil and yield conservation of tomato crops under saline irrigation. Catena 2019, 175, 144-153. [CrossRef]

13. Mohamed, H.; Haggag, W. Biocontrol potential of salinity tolerant mutants of Trichoderma harzianum against Fusarium oxysporum. Braz. J. Microbiol. 2006, 37, 181-191. [CrossRef]

14. Bheemaraya, P.M.B.; Ramesh, Y.S.T.; Amaresh, Y.S.; Naik, M.K. Salinity stress tolerance in native Trichoderma isolates. Environ. Ecol. 2013, 31, 727-729. 
15. Gal-Hemed, I.; Atanasova, L.; Komon-Zelazowska, M.; Druzhinina, I.S.; Viterbo, A.; Yarden, O. Marine isolates of Trichoderma spp. as potential halotolerant agents of biological control for arid-Zone agriculture. Appl. Environ. Microbiol. 2011, 77, 5100-5109. [CrossRef] [PubMed]

16. Ji, N.Y.; Wang, B.G. Mycochemistry of marine algicolous fungi. Fungal Divers. 2016, 80, 301-342. [CrossRef]

17. Blunt, J.W.; Carroll, A.R.; Copp, B.R.; Davis, R.A.; Keyzers, R.A.; Prinsep, M.R. Marine natural products. Nat. Prod. Rep. 2018, 35, 8-53. [CrossRef] [PubMed]

18. Diánez, F.; Santos, M.; Carretero, F.; Marín, F. Trichoderma saturnisporum, a new biological control agent. J. Sci. Food Agric. 2016, 96, 1934-1944. [CrossRef]

19. Diánez, F.; Santos, M.; Carretero, F.; Marín, F. Biostimulant activity of Trichoderma saturnisporum in melon (Cucumis melo). Hortscience 2018, 53, 810-815.

20. Vohník, M.; Borovec, O.; Župan, I.; Vondrášek, D.; Petrtýl, M.; Sudová, R. Anatomically and morphologically unique dark septate endophytic association in the roots of the Mediterranean endemic seagrass Posidonia oceanica. Mycorrhiza 2015, 25, 663-672. [CrossRef]

21. Santos, M.; Diánez, F. Los Antagonistas Microbianos en el Manejo de Micosis de la Parte Aérea de la Planta. In Organismos Para el Control de Patógenos en los Cultivos Protegidos. Prácticas Culturales Para una Agricultura Sostenible; Tello, J.C., Camacho, F., Eds.; Fundacion Cajamar: Almeria, Spain, 2010; pp. 523-528.

22. Marín, F.; Diánez, F.; Santos, M.; Carretero, F.; Gea, F.J.; Castañeda, C.; Navarro, M.J.; Yau, J.A. Control of Phytophthora capsici and Phytophthora parasitica on pepper (Capsicum annuum L.) with compost teas from different sources, and their effects on plant growth promotion. Phytopathol. Med. 2014, 53, 216-228.

23. Santos, M.; Diánez, F.; González, M.; Tello, J.C. Grape marc compost: Microbial studies and suppression of soilborne mycosis in vegetable seedlings. World J. Microbiol. Biotechnol. 2008, 24, 1493-1505. [CrossRef]

24. Sobieralski, K.; Siwulski, M.; Frużyńska-Jóźwiak, D. Growth of aggressive isolates of Trichoderma aggressivum f. europaeum in dependence on temperature and medium. Phytopathologia 2009, 53, 11-18.

25. Santos, M.; Diánez, F.; Carretero, F.; Gea, F.J. Evaluation of selected soils for suppression of Fusarium diseases. Phytopathol. Med. 2017, 56, 278-378.

26. Dela Cruz, T.E.; Wagner, S.; Schulz, B. Physiological responses of marine Dendryphiella species from different geographical locations. Mycol. Prog. 2006, 5, 108-119. [CrossRef]

27. Migheli, Q.; González-Candelas, L.; Dealessi, L.; Camponogara, A.; Ramón-Vidal, D. Transformants of Trichoderma longibrachiatum overexpressing the $\beta$-1,4-Endoglucanase gene egl1 show enhanced biocontrol of Pythium ultimum on cucumber. Biol. Control 1998, 88, 673-677.

28. Yuan, M.; Huang, Y.; Ge, W.; Jia, Z.; Song, S.; Zhang, L.; Huang, Y. Involvement of jasmonic acid, ethylene and salicylic acid signaling pathways behind the systemic resistance induced by Trichoderma longibrachiatum H9 in cucumber. BMC Genom. 2019, 20, 144-157. [CrossRef] [PubMed]

29. De Palma, M.; D’Agostino, N.; Proietti, S.; Bertini, L.; Lorito, M.; Ruocco, M.; Caruso, C.; Chiusano, M.L.; Tucci, M. Suppression subtractive hybridization analysis provides new insights into the tomato (Solanum lycopersicum L.) response to the plant probiotic microorganism Trichoderma longibrachiatum MK1. J. Plant. Physiol. 2016, 190, 79-94. [CrossRef]

30. Porto de Souza, L.; Blandon, L.M.; Rodrigues, C.; Cândido, M.; de Melo, G.V.; Pereira, G.; de Oliveira, J.; Soccol, C.R. Potential applications of plant probiotic microorganisms in agriculture and forestry. AIMS Microbiol. 2017, 3, 629-648. [CrossRef]

31. Sharma, V.; Shanmugam, V. Unraveling the multilevel aspects of least explored plant beneficial Trichoderma saturnisporum isolate GITX-Panog. Eur. J. Plant Pathol. 2018, 152, 169-183. [CrossRef]

32. Meng, J.; Cheng, W.; Heydari, H.; Wang, B.; Zhu, K.; Konuklugil, B.; Lin, W. Sorbicillinoid-based metabolites from a sponge-derived fungus Trichoderma saturnisporum. Mar. Drugs 2018, 16, 226-241. [CrossRef]

33. Ospina-Giraldo, M.D.; Royse, D.M.; Thon, M.R.; Chen, X.; Romaine, C.P. Phylogenetic relationships of Trichoderma harzianum causing mushroom green mold in Europe and North America to other species of Trichoderma from world-wide sources. Mycologia 1998, 90, 76-81. [CrossRef]

34. Samuels, G.J.; Dodd, S.L.; Gams, W.; Castlebury, L.A.; Petrini, O. Trichoderma species associated with the green mold epidemic of commercially grown Agaricus bisporus. Mycologia 2002, 94, 146-170. [CrossRef] [PubMed]

35. Gajera, H.; Domadiya, R.; Patel, S.; Kapopara, M.; Golakiya, B. Molecular mechanism of Trichoderma as bio-control agents against phytopathogen system-A review. Curr. Res. Microbiol. Biotechnol. 2013, 1, 133-142. 
36. Khan, M.R.; Mohiddin, F.A. Trichoderma: Its Multifarious Utility in Crop Improvement. In Crop Improvement Through Microbial Biotechnology. New and Future Developments in Microbial Biotechnology and Bioengineering; Aligarh Muslim University: Aligarh, India; Srinagar, India, 2018; Chapter 13; pp. 263-291.

37. Adnan, M.; Islam, W.; Shabbir, A.; Khan, K.A.; Ghramh, H.A.; Huang, Z.; Chen, H.Y.H.; Lu, G. Plant defense against fungal pathogens by antagonistic fungi with Trichoderma in focus. Microb. Pathog. 2019, 129, 7-18. [CrossRef] [PubMed]

38. European Comission. Sustainable Use of Pesticides. Available online: https://ec.europa.eu/food/plant/ pesticides/sustainable_use_pesticides (accessed on 12 May 2019).

(C) 2019 by the authors. Licensee MDPI, Basel, Switzerland. This article is an open access article distributed under the terms and conditions of the Creative Commons Attribution (CC BY) license (http://creativecommons.org/licenses/by/4.0/). 